\title{
Evaluation of Antihelmintic Activity of Indigenous Plants Found in India Including Butea Monosperma, Origanum Majorana, Piper Longum and Embelia Ribes And GC-MS Phytochemical Analysis of Plant Extracts
}

\author{
Kiran Giri ${ }^{1, *}$, Aradhana Singh ${ }^{2}$, Kamlesh M. Palandurkar ${ }^{3}$, Tuhina Banerjee ${ }^{2}$, Satish Chaurasia ${ }^{4}$
}

Kiran Giri ${ }^{1, *}$, Aradhana Singh ${ }^{2}$, Kamlesh M. Palandurkar ${ }^{3}$, Tuhina Banerjee $^{2}$, Satish Chaurasia ${ }^{4}$

'Department of Pharmacology, Institute of Medical Sciences, Banaras Hindu University, Varanasi, 221004, INDIA.

${ }^{2}$ Department of Microbiology, Institute of Medical Science, Banaras Hindu University, Varanasi, 221004, INDIA.

${ }^{3}$ Department of Biochemistry, Institute of Medical Sciences, Banaras Hindu University, Varanasi, 221004, INDIA.

${ }^{4}$ Department of Pharmacology, Institute of Medical Sciences, Banaras Hindu University, Varanasi, 221004, INDIA.

\section{Correspondence}

Kiran Giri

Department of Pharmacology, Institute of Medical Sciences, Banaras Hindu University, Varanasi, 221004, INDIA.

Phone no: 9146814727

E-mail: drkirangiri@gmail.com

History

- Submission Date: 09-07-2021;

- Review completed: 11-08-2021;

- Accepted Date: 31-08-2021.

DOI : 10.5530/pj.2021.13.186

Article Available online http://www.phcogj.com/v13/i6

Copyright

(C) 2021 Phcogj.Com. This is an openaccess article distributed under the term of the Creative Commons Attribution 4.0 International license.

\begin{abstract}
Introduction: Antimicrobial agents are an essential tool in reducing the burden of the infectious diseases. This study aimed to comprehensively determine the antihelmintic activity of indigenous plants found in India including Butea monosperma, Origanum majorana, Piper longum and Embelia ribes. Methodology Additionally, the profiling of the phytochemical composition of the extracts was done. The preparation of the extract was done using Maceration method. For determination of antihelmintic activity Eisenia fetida were used. The gas chromatography-mass analysis was carried out in GCMS-QP-2010 plus system). Result and conclusion: Aqueous extracts of Embelia ribes and Origanum majorana did not show anthelmintic activity at any of the tested concentrations. Aqueous extract of Butea monosperma showed antihelmintic activity at $20 \mathrm{mg} / \mathrm{ml}$ and $10 \mathrm{mg} / \mathrm{ml}$ at 1 hour and 2-hour time interval respectively. The aqueous extract of Piper longum showed activity at concentration $20 \mathrm{mg} / \mathrm{ml}$ and $10 \mathrm{mg} / \mathrm{ml}$ at the time interval of 1 hour and 3-hour respectively.
\end{abstract}

Key words: Embelia ribes, Origanum majorana, Butea monosperma, Antihelmintic.

\section{INTRODUCTION}

Antimicrobial agents are an essential tool in reducing the burden of the infectious diseases. However, the rapid emergence of multidrug resistant strains has posed a significant threat to public health. ${ }^{1,2}$ Additionally, slow pace of new antibiotics development and availability of fewer options of drugs has provided the thrust to discover nature for formulations with novel targets and effective activity. ${ }^{3}$ World health organisation (WHO) suggests medicinal plants as best source for obtaining a variety of drugs. ${ }^{4}$ Indian population has been using a number of plant species as traditional medicine since a long time, even for the cure of infectious diseases.$^{5}$ But the experimental data regarding the in-vivo and in-vitro efficacy of these plants are limited. Currently the call for herbal drug treatments for different infectious diseases has increased and a variety of plants are explored for newer drug development globally .

Among the various neglected tropical diseases (NTDs), soil transmitted helminths like roundworms, hookworms constitute a major burden in developing countries including India. Several local remedies of plant origin have been tried for treating these infections without proper documentation. ${ }^{6}$ As rural population in these lowincome countries has access to the plant-based formulations easily as compared to synthetic drugs, therefore study of these plant based remedies are often helpful.

An individual plant species contains thousands of different metabolites, however, no single platform has been known to measure them all. ${ }^{7}$ Different separation techniques such as gas chromatography (GC) and liquid chromatography (LC) has been used in combinations with detection techniques such as mass spectrophotometry (MS), nuclear magnetic resonance (NMR), Ultra-voilet (UV) etc for accurate analysis.

This study aimed to comprehensively determine the antihelmintic activity of indigenous plants found in India including Butea monosperma, Origanum majorana, Piper longum and Embelia ribes. Additionally, the profiling of the phytochemical composition of the extracts was done.

\section{MATERIALS AND METHODS}

\section{Chemical and anthelmintics}

Methanol used for the extract preparation was of analytical grade (Sigma- Aldrich Chemical Pvt Ltd., India). Albendazole (MP Biomedicals, LLC, USA) was used as the standard control.

\section{Plant materials and extraction methods}

Seeds of Butea monosperma and Origanum majorana and fresh fruit of Embeliaribes and Piper longum were included in the study. The seeds and fruits were purchased from an ayurvedic store in the local market of Varanasi. The authentication of seeds and fruits were done from the Department of Dravyaguna, Institute of Medical Sciences,Banaras Hindu University,Varanasi. The name of the plant was checked with http://www.theplantlist.org (Accessed on 14thAugust 2020).The shade dried seeds and fruits were crushed using mortar and 
pestle to a fine powder. The powder was then weighted individually and stored in a stoppered container and were labeled. The containers were kept away from direct heat and moisture.The preparation of the extract was done using Maceration method. Briefly, 500 gm of crushed seeds and fruits were taken in a stoppered flask and filled with $1 \mathrm{~L}$ of methanol/ distilled water (solvent). These flasks were incubated at room temperature for about a period of 3 days with frequent agitation. After the following days the solvent were filtered out by using Whatman \#1 filter paper and were heated in a round bottom flask at a temperature of $55^{\circ} \mathrm{C}$ until the moisture content from the extract was evaporated.

\section{Micro-organisms}

Adult Earthworm (Eisenia fetida) were collected from the Institute of Agriculture sciences, Banaras Hindu University, India and cleaned with fresh water. The helminthes were kept in phosphate buffer saline (PBS) until in vitro experiments was started.

\section{Determination of in vitro anthelmintic activity}

The anthelmintic assay was performed in vitro using adult earthworms owing to their anatomical and physiological resemblance with the intestinal roundworms, parasites of human beings for preliminary evaluation of anthelmintic activity. Earthworms each of average length $6 \mathrm{~cm}$ were placed in petri dishes containing $2 \mathrm{ml}$ of various plant extract concentration, $5 \mathrm{mg} / \mathrm{ml}, 10 \mathrm{mg} / \mathrm{ml}$ and $20 \mathrm{mg} / \mathrm{ml}$ of solutions. Albendazole solution was used as reference standard drug and saline as control. The worms were observed at $0.5 \mathrm{hr}, 1 \mathrm{hr}, 2 \mathrm{hr}, 3 \mathrm{hr}$ for the paralysis after incubating at $37^{\circ} \mathrm{C}$.Paralysis was said to occur when the worms were not able to move. The scoring system has been shown in Table 1.

\section{Gas chromatography-mass spectrometry (GC-MS) analysis}

Samples were injected with a split ratio of $10: 1$ using a split injection mode. The gas chromatography-mass analysis was carried out in GCMS-QP-2010 plus system (Shimadzu Co., Kyoto, Japan). The column used was Rxi-5 SIL MS $(30 \mathrm{M} \times 0.25 \mathrm{~mm}$ id $\times 0.25 \mathrm{u}$, film thickness). The mass spectrometer was tuned according to the manufacturer's recommendations. Injection temperature was $260^{\circ} \mathrm{C}$, the interface set to $270^{\circ} \mathrm{C}$ and the ion source adjusted to $220^{\circ} \mathrm{C}$. Helium was used as the carrier gas and the flow rate of $1.21 \mathrm{ml} \mathrm{min}^{-1}$ was maintained. The temperature program included 2 minutes isothermal heating at $60^{\circ} \mathrm{C}$, followed by $250^{\circ} \mathrm{C}$ for 2 minutes further $280^{\circ} \mathrm{C}$ for 21 minutes. The relative percentage amount of each component was measured by comparing the average peak area of each component to the total area. The chromatograms and mass spectra were evaluated using the masslab program (ThermoQuest, Manchester, UK). A retention time and mass spectral library for automatic peak quantification of metabolite derivatives was implemented within the masslab method format.

\section{Ethical approval}

The study was approved by the Institute ethical committee, IMS, BHU, ethical approval number: Dean/2018/CAEC/818. Informed consent was taken from the human participants whose samples were included in the study.

\section{RESULTS}

\section{Anthelmintic activity}

Extract of Butea monosperma, Origanum majorana and Piper longum containing $5 \mathrm{mg} / \mathrm{ml}, 10 \mathrm{mg} / \mathrm{ml}$ and $20 \mathrm{mg} / \mathrm{ml}$ produced dose dependent paralysis ranging from loss of motility to loss of response to external stimuli. The methanolic extract ofPiper longum showed antihelmintic activity at concentration $20 \mathrm{mg} / \mathrm{ml}$ and $10 \mathrm{mg} / \mathrm{ml}$ at the time interval
Table 1: Scoring system for the assessment of drug effect on motility of Earthworms.

\begin{tabular}{|c|c|}
\hline $\begin{array}{l}\text { Motility } \\
\text { score }\end{array}$ & Appearance of the helminth \\
\hline 0 & Highly motile, similar to the motion at the start of the culture \\
\hline 1 & Significant movement in a normal fashion \\
\hline 2 & Sluggish motility, very limited movement \\
\hline 3 & Motile only on stimulation \\
\hline 4 & $\begin{array}{l}\text { Non-motile, no movement observable even in the presence of } \\
\text { stimulus. }\end{array}$ \\
\hline
\end{tabular}

Table 2: Anthelmintic activity of plant extracts with reference to standard drug.

\begin{tabular}{|c|c|c|c|c|c|}
\hline PL (Al) & $t=0 h$ & $\mathrm{t}=0.5 \mathrm{~h}$ & $t=1.0 h$ & $t=2.0 h$ & $t=3.0 h$ \\
\hline $5 \mathrm{mg} / \mathrm{ml}$ & 0 & 1 & 2 & 3 & 4 \\
\hline $10 \mathrm{mg} / \mathrm{ml}$ & 0 & 2 & 4 & - & - \\
\hline $20 \mathrm{mg} / \mathrm{ml}$ & 0 & 4 & - & - & - \\
\hline \multicolumn{6}{|l|}{ BM (Al) } \\
\hline $5 \mathrm{mg} / \mathrm{ml}$ & 0 & 0 & 1 & 3 & 4 \\
\hline $10 \mathrm{mg} / \mathrm{ml}$ & 0 & 1 & 2 & 4 & - \\
\hline $20 \mathrm{mg} / \mathrm{ml}$ & 0 & 2 & 4 & - & - \\
\hline \multicolumn{6}{|l|}{ OM (Al) } \\
\hline $5 \mathrm{mg} / \mathrm{ml}$ & 0 & 0 & 2 & 4 & - \\
\hline $10 \mathrm{mg} / \mathrm{ml}$ & 0 & 1 & 4 & - & - \\
\hline $20 \mathrm{mg} / \mathrm{ml}$ & 0 & 2 & 4 & - & - \\
\hline \multicolumn{6}{|l|}{ ER (Aq) } \\
\hline $5 \mathrm{mg} / \mathrm{ml}$ & 0 & 1 & 1 & 1 & 1 \\
\hline $10 \mathrm{mg} / \mathrm{ml}$ & 0 & 1 & 1 & 1 & 1 \\
\hline $20 \mathrm{mg} / \mathrm{ml}$ & 0 & 1 & 2 & 2 & 2 \\
\hline \multicolumn{6}{|l|}{ OM (Aq) } \\
\hline $5 \mathrm{mg} / \mathrm{ml}$ & 0 & 1 & 1 & 2 & 2 \\
\hline $10 \mathrm{mg} / \mathrm{ml}$ & 0 & 1 & 2 & 2 & 2 \\
\hline $20 \mathrm{mg} / \mathrm{ml}$ & 0 & 2 & 2 & 2 & 2 \\
\hline \multicolumn{6}{|l|}{ BM (Aq) } \\
\hline $5 \mathrm{mg} / \mathrm{ml}$ & 0 & 1 & 2 & 3 & 4 \\
\hline $10 \mathrm{mg} / \mathrm{ml}$ & 0 & 2 & 3 & 4 & - \\
\hline $20 \mathrm{mg} / \mathrm{ml}$ & 0 & 3 & 4 & - & - \\
\hline \multicolumn{6}{|l|}{ PL (Aq) } \\
\hline $5 \mathrm{mg} / \mathrm{ml}$ & 0 & 0 & 1 & 2 & 3 \\
\hline $10 \mathrm{mg} / \mathrm{ml}$ & 0 & 0 & 2 & 3 & 4 \\
\hline $20 \mathrm{mg} / \mathrm{ml}$ & 0 & 2 & 4 & - & - \\
\hline \multicolumn{6}{|c|}{ Albendazole } \\
\hline $5 \mathrm{mg} / \mathrm{ml}$ & 0 & 1 & 2 & 2 & 4 \\
\hline $10 \mathrm{mg} / \mathrm{ml}$ & 0 & 2 & 2 & 4 & - \\
\hline $20 \mathrm{mg} / \mathrm{ml}$ & 0 & 2 & 2 & 4 & - \\
\hline \multicolumn{6}{|l|}{ Control } \\
\hline- & 0 & 0 & 0 & 0 & 0 \\
\hline
\end{tabular}

Abbreviations used: PL- Piper longum, BM- Butea monosperma, OM- Origanum majorana, ER-Embelia ribes, Al- Alcoholic, Aq- Aqueous

of 0.5-hour and 1hour respectively. The methanolic extract of Butea monosperma showed activity at concentration $20 \mathrm{mg} / \mathrm{ml}$ and $10 \mathrm{mg} / \mathrm{ml}$ at 1 hour and 2-hour time interval respectively. The methanolic extract of Origanum majorana showcased anthelmintic activity at all the tested concentration of $20 \mathrm{mg} / \mathrm{ml}, 10 \mathrm{mg} / \mathrm{ml}$ and $5 \mathrm{mg} / \mathrm{ml}$ at the time interval of 1-hour, 1 hour and 2 hours respectively. Aqueous extracts ofEmbeliaribes and Origanum majorana did not show anthelmintic activity at any of the tested concentrations. Aqueous extract of Butea monosperma showed anthelmintic activity at $20 \mathrm{mg} / \mathrm{ml}$ and $10 \mathrm{mg} / \mathrm{ml}$ at 1 hour and 2-hour time interval respectively. The aqueous extract of Piperlongum showed activity at concentration $20 \mathrm{mg} / \mathrm{ml}$ and $10 \mathrm{mg} / \mathrm{ml}$ 
at the time interval of 1 hour and 3-hour respectively. The complete score of all the tested extracts at different time intervals is shown in Table 2. In the standard drug, Albendazole, anthelmintic activity was seen at $20 \mathrm{mg} / \mathrm{ml}, 10 \mathrm{mg} / \mathrm{ml}$ and $5 \mathrm{mg} / \mathrm{ml}$ at the time interval of 2 -hour, 2-hour and 3-hour respectively. The graph showing paralytic score of the extracts with reference to the albendazole at different concentrations and time intervals has been shown in figure 1, 2 and 3 . In the control plate the active motility was seen throughout the experiment.

\section{GC-MS analysis of Butea monosperma extract}

The complete list of the compounds identified in the GC-MS analysis of the plant extracts of Butea monospermahas been included in Table 3. Total 20 components were reported with 1,2- Benzenedicarboxylic acid as the single most dominant component in the extracts of Butea monosperma (92.42\%) (Figure 4). One component remains unidentified through GC-MS analysis. The other compounds reported includes beta-D-Glucopyranose, 1-6-anhydro-(1.24\%), 3-O-Methyl-dglucose $(4.11 \%)$ andn-Hexadecanoic acid $(0.49 \%)$.

\section{GC-MS analysis of Origanum majorana extract}

The results pertaining to GC-MS analysis of the extract of Origanum majorana lead to identification of a total of 35 compounds (Figure 5). Of the total compounds identified 1,2- Benzene dicarboxylic acid was the most prevailing compound (46.67\%). Other compounds identified in the Origanum majorana extract includes Octadecenoic acid (Z) (16.94\%), methyl estern-Hexadecanoic acid (5.68\%), 9-Octadecenoic acid (Z)-, methyl ester (5.48\%), Hexadecanoic acid, methyl ester (3.47\%), 9-Octadecenoic acid (Z)-, 2,3-dihydroxypropyl ester (4.47\%), Glutaric acid, hex-4-yn-3-yl dodec-9-yn-1-yl ester (4.10\%) and Piperine(3.57\%).

\section{GC-MS analysis of Piper longum extract}

A total of 63 compounds were identified in the extract of Piper longum through GC-MS analysis (Figure 6). The different compounds reported includes 8-Heptadecene (1.37\%), 1-Chlorooctadecane (2.38\%), Bis(2ethylhexyl) phthalate (16.2\%), Undec-10-ynoic acid, tridec-2-yn-1-yl

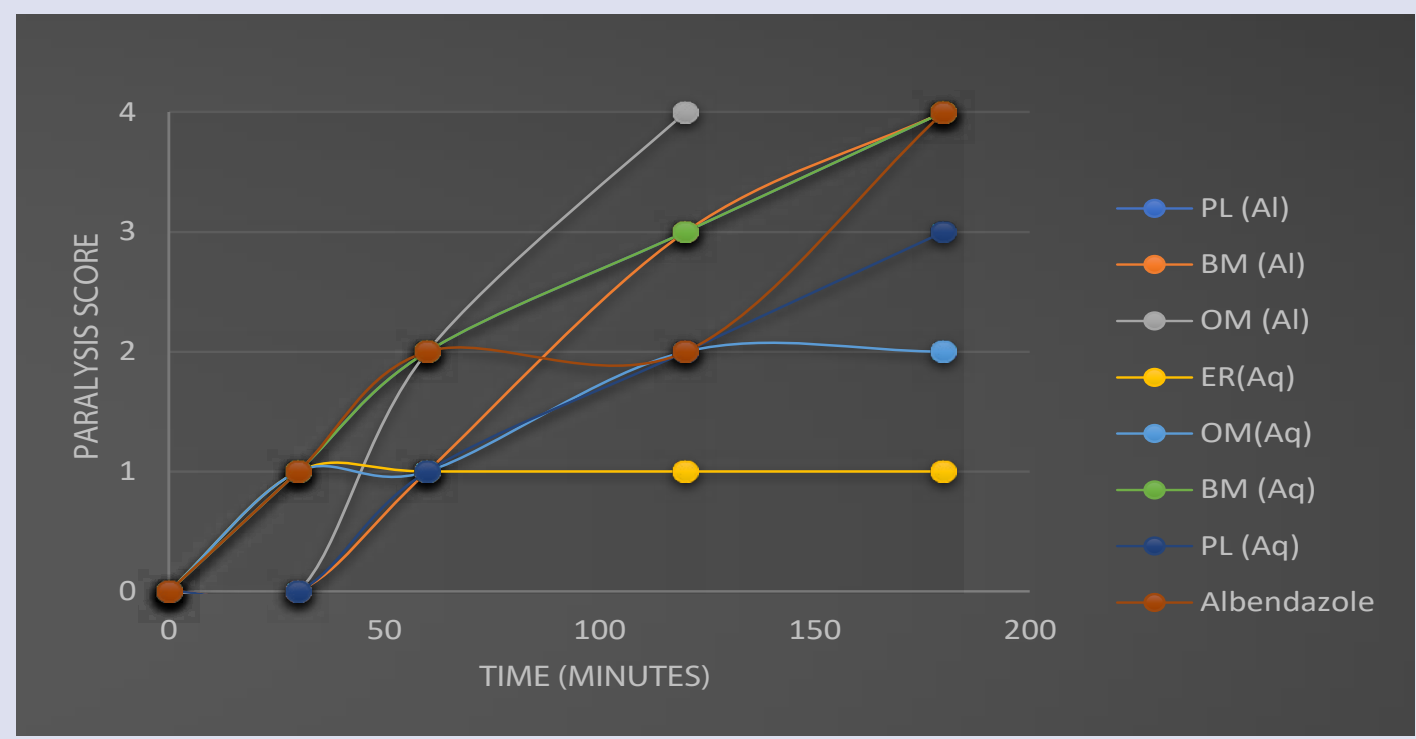

Figure 1: Paralytic score of earthworms treated with the extracts and albendazole at different time intervals at $5 \mathrm{mg} / \mathrm{ml}$ concentration.

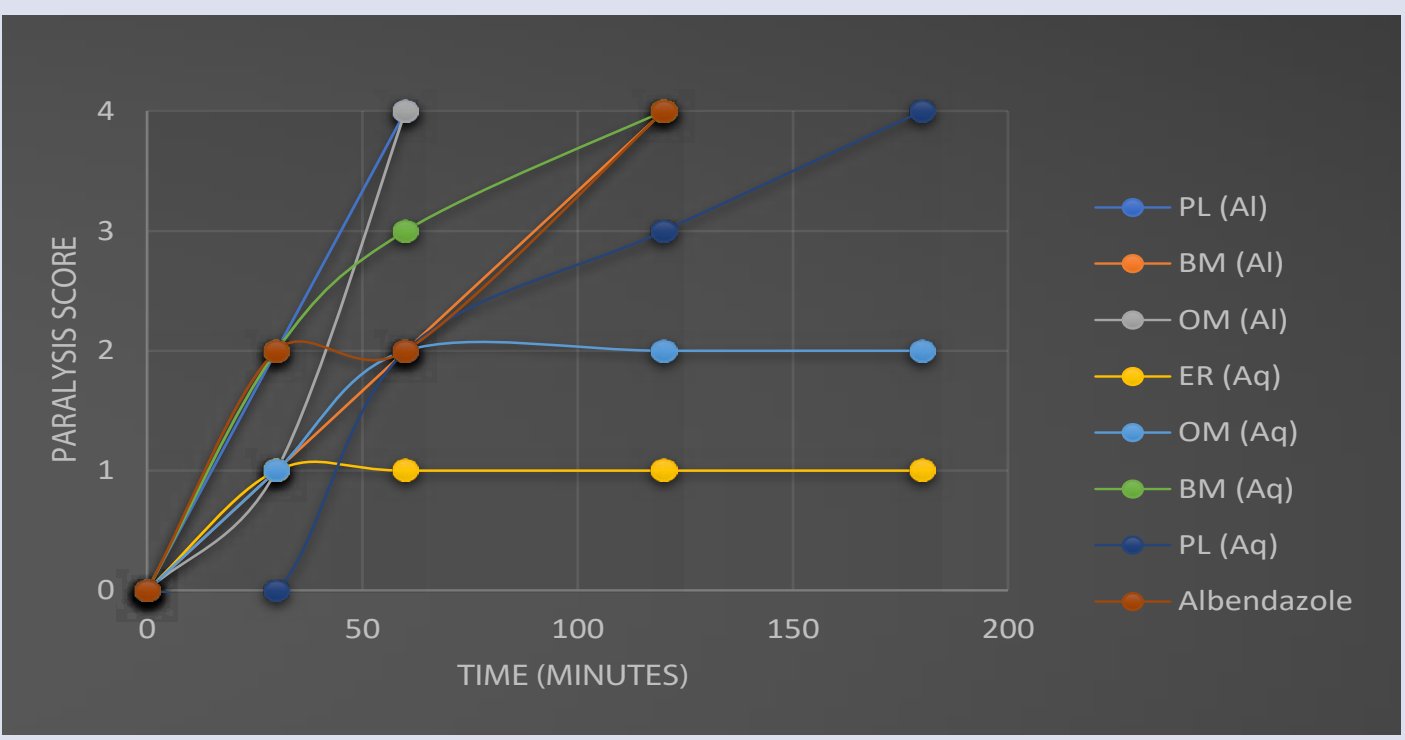

Figure 2: Paralytic score of earthworms treated with the extracts and albendazole at different time intervals at $10 \mathrm{mg} / \mathrm{ml}$ concentration. 


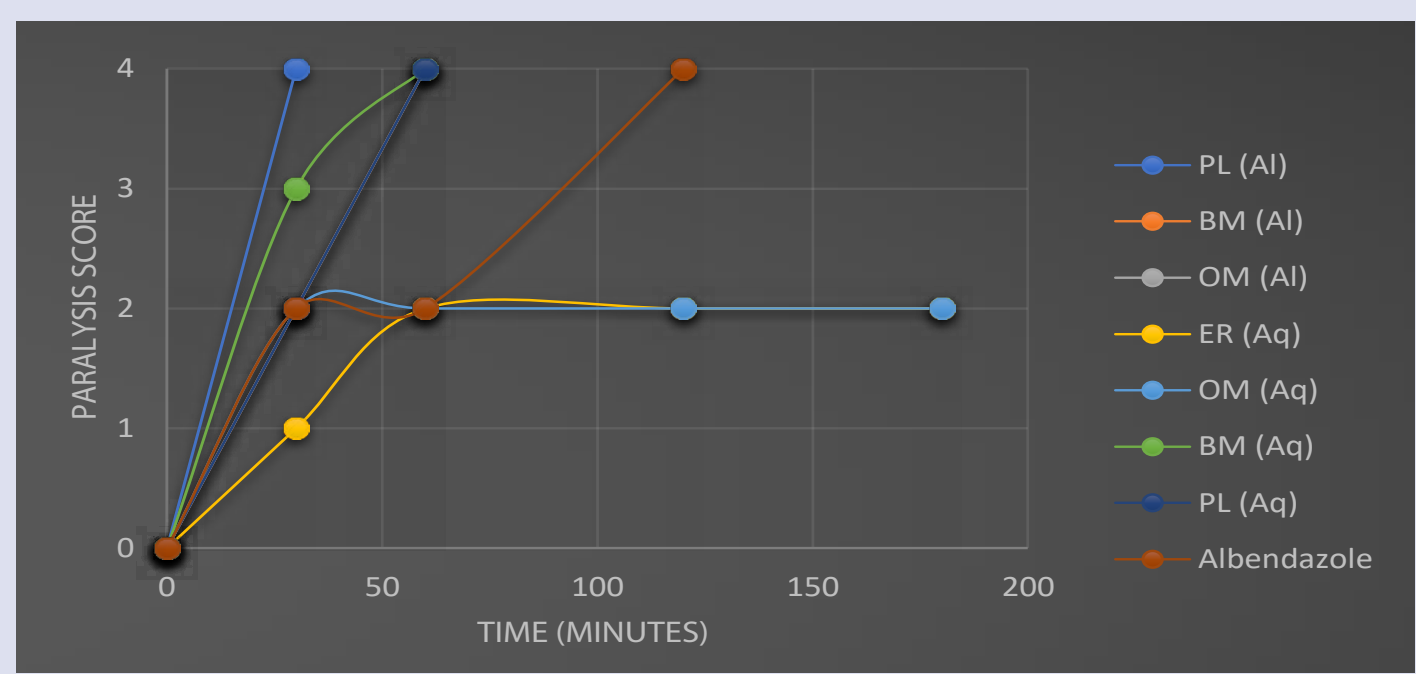

Figure 3: Paralytic score of earthworms treated with the extracts and albendazole at different time intervals at $20 \mathrm{mg} / \mathrm{ml}$ concentration.

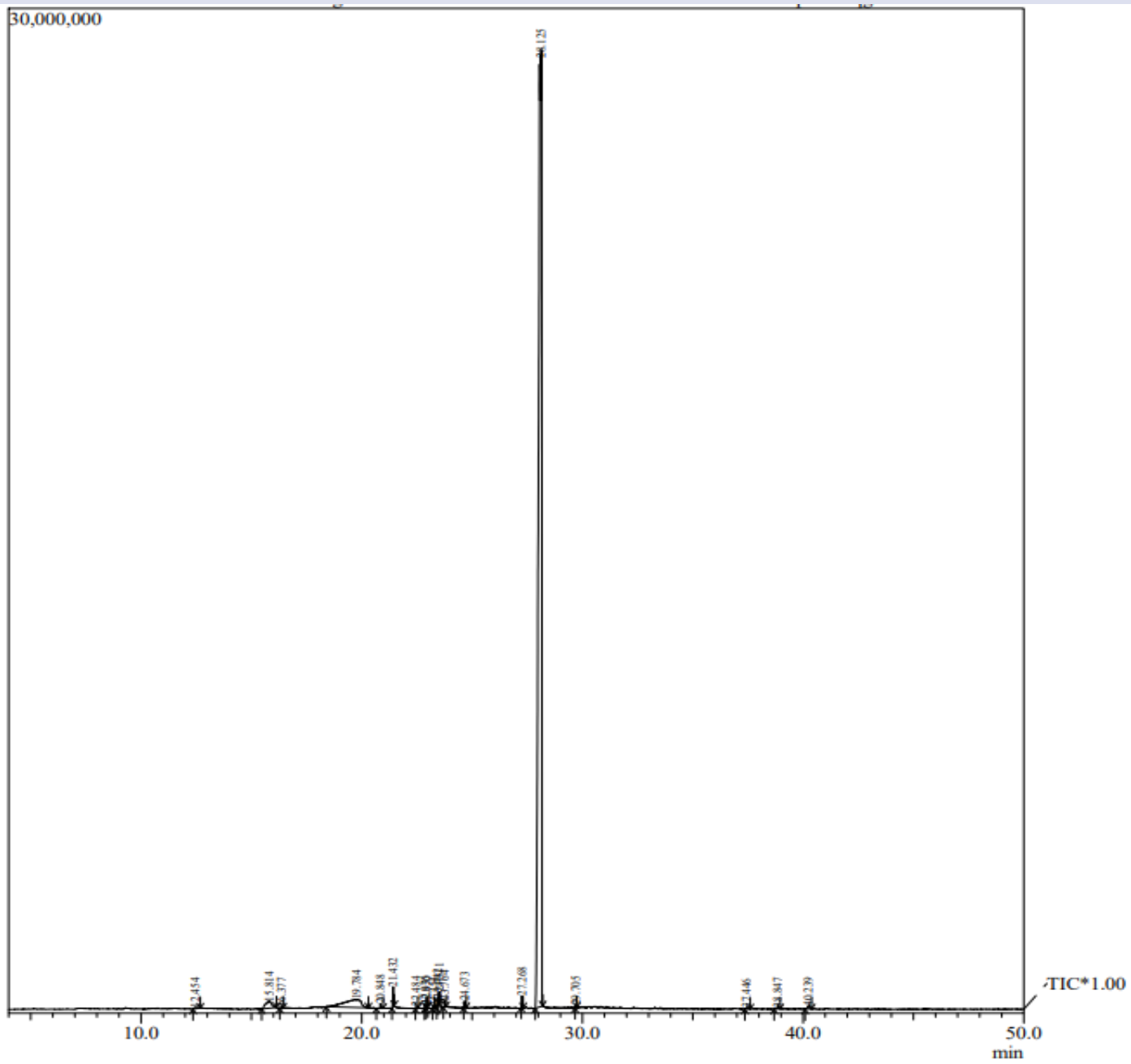

Figure 4: Chromatogram of Butea monosperma extract. 


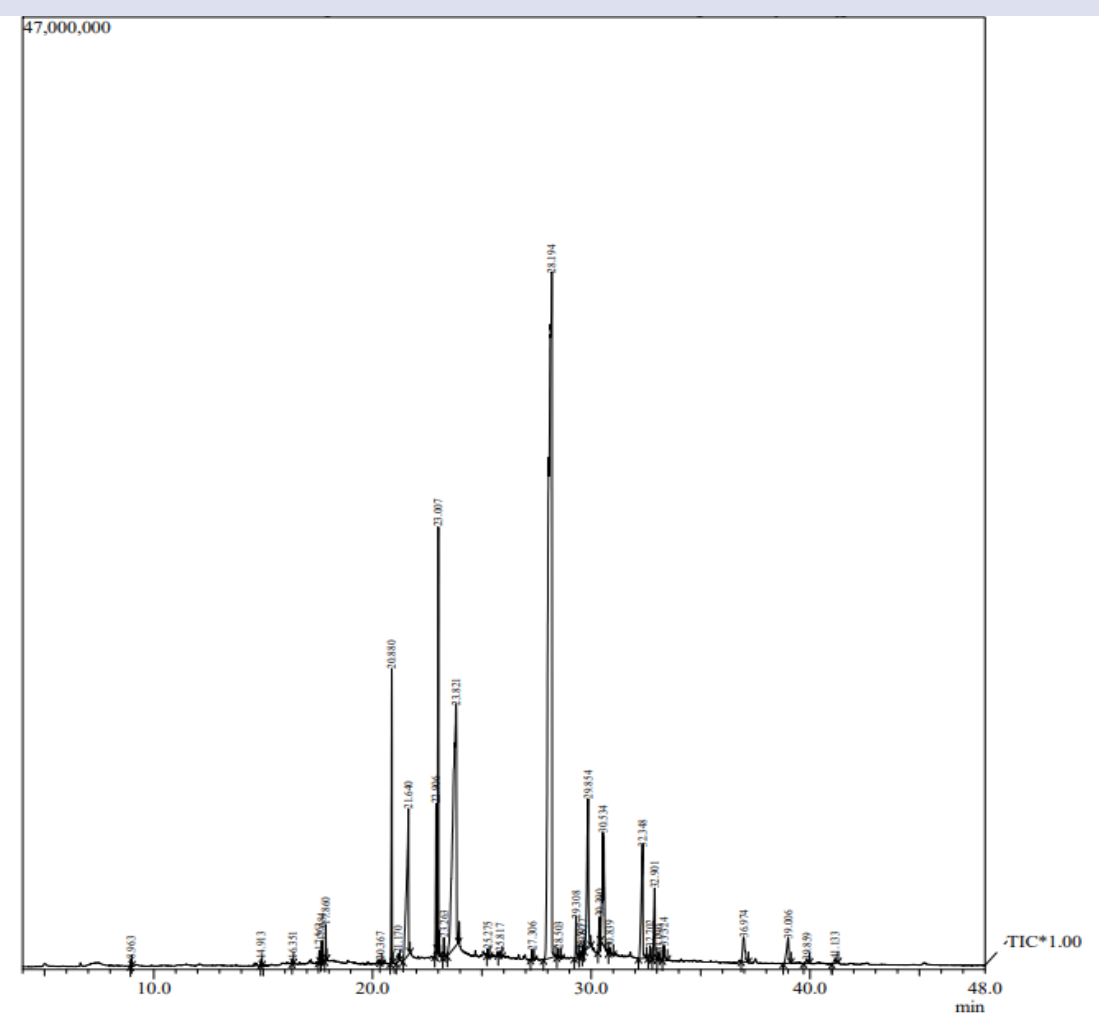

Figure 5: Chromatogram of Origanum majorana extract.

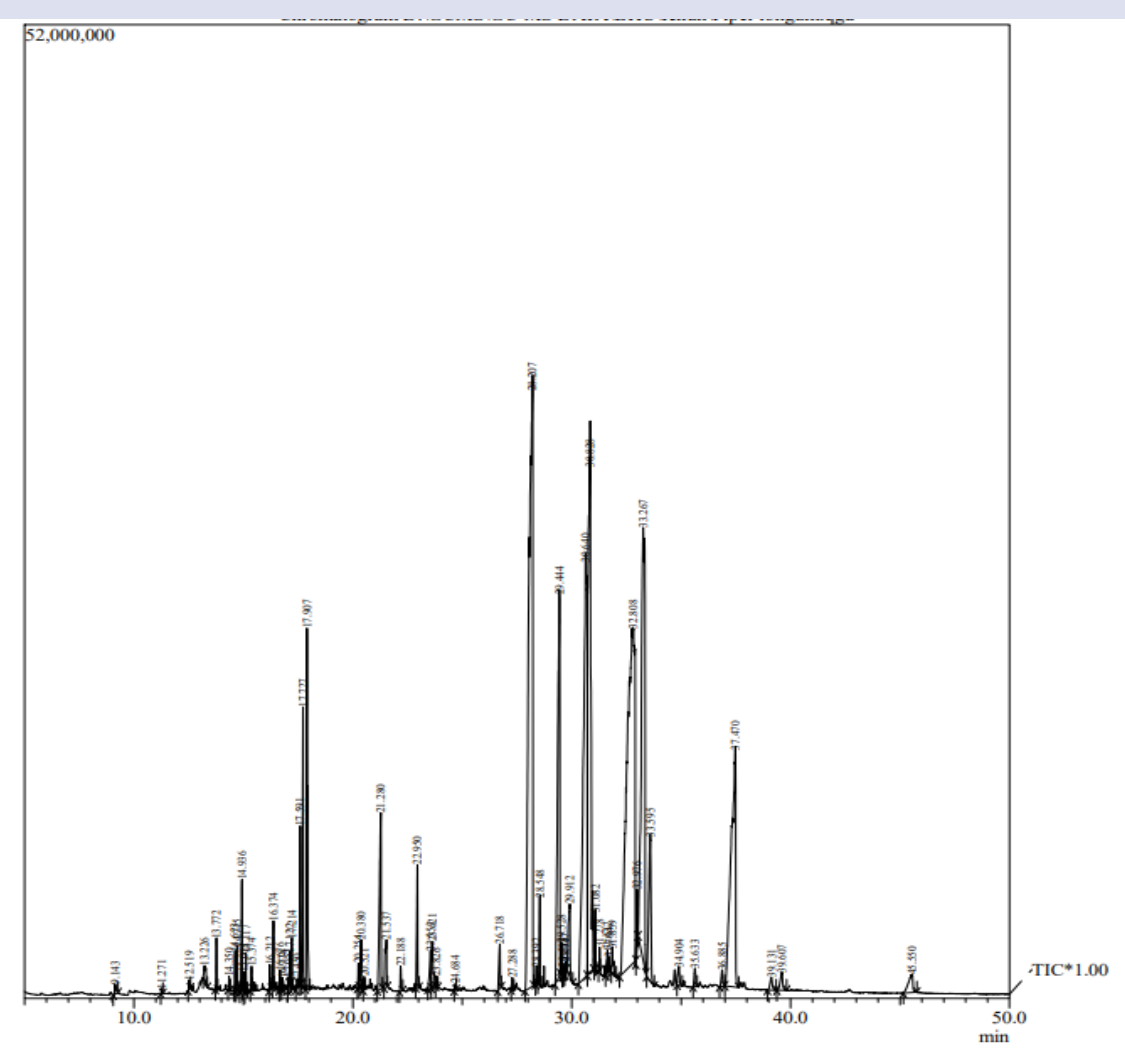

Figure 6: Chromatogram of Piper longum extract. 
Giri K, et al.: Evaluation of Antihelmintic Activity of Indigenous Plants Found in India Including Butea Monosperma, Origanum Majorana, Piper Longum and Embelia Ribes And GC-MS Phytochemical Analysis of Plant Extracts

ester (11.04\%), (2E,4E)-N-Isobutyloctadeca-2,4-dienamide $(1.08 \%)$, Piperine (18.57\%), (2E,4E,14E)-N-Isobutylicosa-2,4,14-trienamide (10.97\%) and Butane, 2-(2,2-dichloro-1,3-dimethylcyclopropyl) (7.64).

\section{DISCUSSION}

According to $\mathrm{WHO}, 85 \%$ of the population in developing countries depends on the traditional medicine for human and animal care. ${ }^{8}$ Plants are rich source of bioactive compounds which boosts immune system, reduce oxidative damages and are known to be effective against a number of pathogenic microbes. ${ }^{9,10}$ In the present study, the extract of Butea monosperma, Origanum majorana and Piper longum showed anthelmintic activity. However, the extract of plant Embelia ribes was not found to be effective against the tested helminth in the present assay.

Butea monosperma is widely distributed throughout India, Burma and Ceylon and finds use both commercially as well as medicinally with every plant part. ${ }^{11}$ In the present study methanolic as well as the aqueous extract of Butea monosperma showed better anthelmintic activity as compared to the standard albendazole. Our results are in concordance with other studies which showed anthelmintic potential of the extracts of Butea monosperma leaves and seeds in different solvents $[8,12]$. A study reported that methanolic extract of the seeds of Butea monosperma showed potent anthelmintic activity against Caenorhabditis elegans..$^{12}$ The crude powder of Butea monosperma seeds has shown time-dependent and dose-dependent in vivo anthelmintic activity in sheeps with mixed species of gastrointestinal nematodes. ${ }^{13}$

Origanum majorana also called as marjoram is cold sensitive perennial herb. Commonly used for seasoning of salads, soups, dressings and for herbal teas.${ }^{14}$ In the present study, Origanum majorana showed anthelmintic activity against the Earthworm model. Studies have reported effective antibacterial, antiviral and nematocidal activity of theOriganum plant.${ }^{15-18}$ A recent study demonstrated significant anthelmintic activity of the leaves and stems of Origanum majorana and attributed it to the presence of $\mathrm{p}$-cymene, carvacroland thymol.$^{19}$

The reference of Piper longum comes from ancient times for its medicinal and dietary uses. ${ }^{20}$ In the present study methanolic extract of Piper longum showed better anthelmintic activity as compared to the aqueous extract. However, both the alcoholic and aqueous extract of Piper longum were found to be more effective against the earthworm model used in the present study as compared to the standard drug, albendazole. Many studies from different part of the world have showed the anthelmintic activity of the fruits of Piper longum.$^{21-23} \mathrm{~A}$ study showing the in vitro ovicidal, larvicidal and adulticidal activity of methanolic extract and its fractions from fruits of Piper longum concluded that the methanolic extract and fractions of Piper longum possessed potent anthelmintic activity.$^{24}$

Through GC-MS analysis, 1,2-benzenedicarboxylic acid has been found to be a major constituent in the extracts of Butea monosperma $(92.42 \%)$ and Origanum majorana $(45.67 \%)$. Studies have reported potent antimicrobial activity of 1,2-benzenedicarboxylic acid against a number of pathogenic microbes [25-26]. The compound 1,2-benzenedicarboxylic acid has been reported to be an important component in the extracts of seeds and pods of Acacia nilotica Linn, leaf and bark extracts of Salix subserrata, leaf extractsofGynura segetum showing prominent antimicrobial function . 25-28

In the GC-MS analysis of Piper longum extract, piperine (18.57\%) was found to be most prevailing component which can be an important contributor in the anthelmintic activity of this extract. This result is in agreement with other studies which report effective antimicrobial effect of piperine. ${ }^{29-30}$ A study from Iraq reported the piperine isolated from seeds of Piper nigrum showed effective antimicrobial activity against the tested gram positive as well asgram negative bacteria and
Candida sp. ${ }^{31}$ Piperine has been known to cause DNA damage and it prevents the repair mechanism for the damage ${ }^{32}$

It can be concluded that extract of Butea monosperma, Origanum majorana and Piper longum have anthelmintic property. These plant extracts can be used as a potential alternative of anthelmintic drugs to prevent their overuse and side effects on human health and environment. However, further studies to determine clinical efficacy are required.

\section{ACKNOLEDGMENTS}

We thank the Institute of Medical Sciences, Banaras Hindu University, Varasnasi, India for providing the infrastructure, and other research facility.

\section{CONFLICTS OF INTEREST}

Accordingly, there is no-conflict of interest arising whatsoever with this article.

\section{ACKNOLEDGMENTS}

We thank the Institute of Medical Sciences, Banaras Hindu University, Varasnasi, India for providing the infrastructure, and other research facility.

\section{REFERENCES}

1. Boucher HW, Talbot GH, Bradley JS, Edwards JE, Gilbert D, Rice LB, Scheld M, Spellberg B, Bartlett J. Bad bugs, no drugs: no ESKAPE! An update from the Infectious Diseases Society of America. Clinical infectious diseases. 2009 Jan 1;48(1):1-2.

2. Giamarellou H. Multidrug-resistant Gram-negative bacteria: how to treat and for how long. International Journal of Antimicrobial Agents. 2010 Dec 1;36:S50-4.

3. Iwalokun BA, Ogunledun A, Ogbolu DO, Bamiro SB, Jimi-Omojola $\mathrm{J}$. In vitro antimicrobial properties of aqueous garlic extract against multidrug-resistant bacteria and Candida species from Nigeria. Journal of medicinal food. 2004 Sep 1;7(3):327-33.

4. World Health Organization. The world health report 2002: reducing risks, promoting healthy life. World Health Organization; 2002.

5. Banerjee T, Singh A, Kumar S, Dhanani T, Gajbhiye NA, Koley TK, Maurya A, Filgona J. Ovicidal and larvicidal effects of extracts from leaves of Andrographis paniculata (Burm. f.) Wall. ex Nees against field isolates of human hookworm (Ancylostoma duodenale). Journal of ethnopharmacology. 2019 May 10;235:489-500.

6. Koley TK, Khan Z, Oulkar D, Banerjee T, Singh A, Karkute SG, Banerjee K. Coupling the high-resolution LC-MS characterisation of the phenolic compounds with the antimicrobial and antibiofilm properties of helencha (Enydra fluctuans Lour.). Journal of Food Science and Technology. 2021 Jan 17:1-1

7. Kopka J, Fernie A, Weckwerth W, Gibon Y, Stitt M. Metabolite profiling in plant biology: platforms and destinations. Genome biology. 2004 May;5(6):1-9.

8. Singh G, Singh R, Verma PK, Singh R, Anand A. Anthelmintic efficacy of aqueous extract of Butea monosperma (Lam.) Kuntze against Haemonchus contortus of sheep and goats. Journal of Parasitic Diseases. 2015 Jun;39(2):200-5.

9. Han X, Shen T, Lou H. Dietary polyphenols and their biological significance. International Journal of Molecular Sciences. 2007 Sep;8(9):950-88.

10. Verma PK, Raina $R$, Singh SP, Sultana M. Oxidative stress: pharmacology of vitamin E. J Vet Pharmacol Toxicol. 2011;10(1-2):1-7.

11. Fageria D, Rao D. A review on Butea monosperma (Lam.) kuntze: A great therapeutic valuable leguminous plant. Int. J. Sci. Res. 2015:5:1-8. 
12. Prashanth $D$, Asha MK, Amit A, Padmaja R. Anthelmintic activity of Butea monosperma. Fitoterapia (Milano). 2001;72(4):421-2.

13. Iqbal Z, Lateef M, Jabbar A, Ghayur MN, Gilani AH. In vivo anthelmintic activity of Butea monosperma against Trichostrongylid nematodes in sheep. Fitoterapia. 2006 Feb 1;77(2):137-40.

14. Bagci Y, Kan Y, Dogu S, Çelik SA. The essential oil compositions of Origanum majorana L. cultivated in Konya and collected from MersinTurkey. Indian J. Pharm. Educ. Res. 2017 Jul 1;51:S463-9.

15. Busatta C, Vidal RS, Popiolski AS, Mossi AJ, Dariva C, Rodrigues MR, Corazza FC, Corazza ML, Oliveira JV, Cansian RL. Application of Origanum majorana L. essential oil as an antimicrobial agent in sausage. Food microbiology. 2008 Feb 1;25(1):207-11

16. Walker JF, Santos PD, Schmidt CA, Bittencourt TC, Guimarães AG. Antimicrobial Activity of Marjoram (Origanum Majorana) Essential Oil Against the Multidrug-Resistant Salmonella Enterica Serovar Schwarzengrund Inoculated in Vegetables from Organic Farming. Journal of Food Safety. 2016 Nov;36(4):489-96.

17. Vági $E$, Simándi $B$, Suhajda $A$, Hethelyi E. Essential oil composition and antimicrobial activity of Origanum majorana L. extracts obtained with ethyl alcohol and supercritical carbon dioxide. Food research international. 2005 Jan 1;38(1):51-7.

18. Minami M, Kita M, Nakaya T, Yamamoto $T$, Kuriyama $H$, Imanishi $J$. The inhibitory effect of essential oils on herpes simplex virus type-1 replication in vitro. Microbiology and immunology. 2003 Sep;47(9):681-4

19. Abidi A, Sebai E, Dhibi MO, Darghouth MA, Akkari H. Chemical analyses and evaluation of the anthelmintic effects of Origanum majorana essential oil, in vitro and in vivo studies. Veterinárni medicína. 2020 Nov 26;65(11):495-505

20. Kumar S, Kamboj J, Sharma S. Overview for various aspects of the health benefits of Piper longum linn. fruit. Journal of acupuncture and meridian studies. 2011 Jun 1:4(2):134-40.

21. D'Cruz JL, Nimbkark AY, Kokate CK. Evaluation of fruits of Piper longum Linn. and leaves of Adhatoda vasica Nees for anthelmintic activity. Indian drugs. 1980;17(4):99-101.
22. Kokate CK, Chaudhari GN, Nimbkar AY. Search for anthelmintics of plant origin: activities of volatile principles of Acorus calamus and Piper longum against Ascaris lumbricoides. In4. Asian Symposium on Medicinal Plants and Spices, Bangkok (Thailand), 15-19 Sep 19801980

23. Singh TU, Kumar D, Tandan SK, Mishra SK. Inhibitory effect of essential oils of Allium sativum and Piper longum on spontaneous muscular activity of liver fluke, Fasciola gigantica. Experimental parasitology. 2009 Dec 1;123(4):302-8.

24. Koorse KG, Samraj S, John P, Narayanan PM, Devi SS, Usha PT, Sunilkumar S, Gleeja VL. Anthelmintic activity of fruit extract and fractions of Piper longum L. In vitro. Pharmacognosy Journal. 2018;10(2).

25. Shoge M. Antimicrobial activity of 1, 2 butyldecyl ester isolated from Acacia niloti.2014

26. Singh R, Singh SK, Maharia RS, Garg AN. Identification of new phytoconstituents and antimicrobial activity in stem bark of Mangifera indica (L.). Journal of pharmaceutical and biomedical analysis. 2015 Feb 25;105:150-5.

27. Hussain $H$, Badawy A, Elshazly A, Elsayed A, Krohn K, Riaz M, Schulz B. Chemical constituents and antimicrobial activity of Salix subserrata. Records of Natural Products. 2011;5(2):133.

28. Seow LJ, Beh HK, Ibrahim P, Sadikun A, Asmawi MZ. Antimicrobia activity of Gynura segetum's leaf extracts and its active fractions. CELLMED. 2012;2(2):20-1.

29. Zarai Z, Boujelbene E, Salem NB, Gargouri Y, Sayari A. Antioxidant and antimicrobial activities of various solvent extracts, piperine and piperic acid from Piper nigrum. Lwt-Food science and technology. 2013 Mar 1;50(2):634-41.

30. Takooree H, Aumeeruddy MZ, Rengasamy KR, Venugopala KN Jeewon R, Zengin G, Mahomoodally MF. A systematic review on black pepper (Piper nigrum L.): From folk uses to pharmacological applications. Critical reviews in food science and nutrition. 2019 Jun 27;59(sup1):S210-43.

31. Aldaly ZT. Antimicrobial activity of piperine purified from Piper nigrum. J. Basrah Res. 2010;36:54-61.

32. Fofaria NM, Kim SH, Srivastava SK. Piperine causes G1 phase cell cycle arrest and apoptosis in melanoma cells through checkpoint kinase-1 activation. PloS one. 2014 May 7;9(5):e94298. 


\section{GRAPHICAL ABSTRACT}

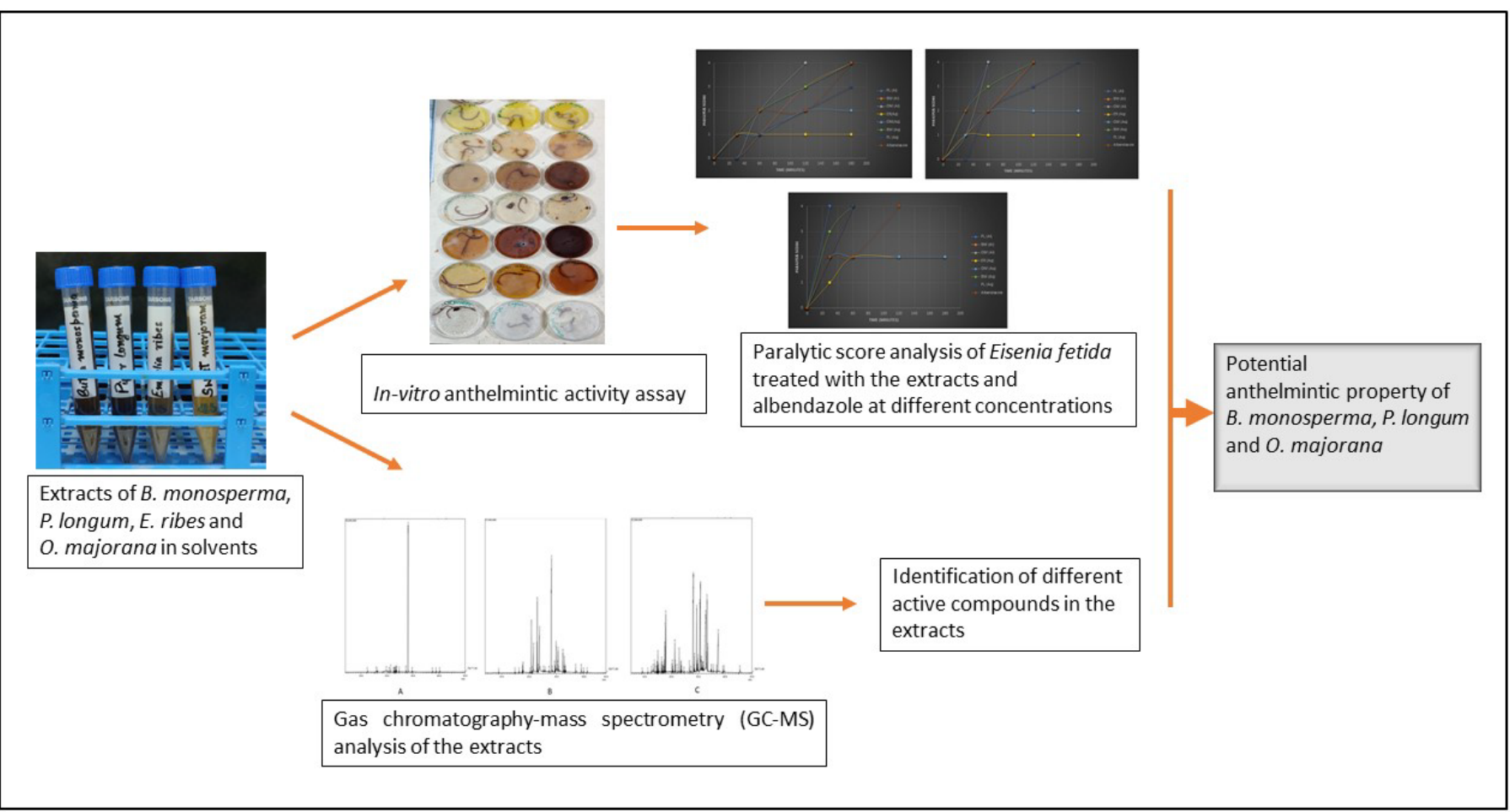

\section{ABOUT AUTHORS}

- Dr. Tuhina Banerjee is a Professor (M.D., Ph. D) in Department of Microbiology, Institute of Medical Sciences, Banaras Hindu University, Varanasi, India. Her research interest includes clinical parasitology with special reference to neglected tropical diseases.

- Aradhana Singh is a senior research fellow in Department of Microbiology, Institute of Medical Sciences, Banaras Hindu University, Varanasi, India. Her research interests include parasitic diseases, antimicrobial activity of plant extracts and drug resistance.

- Dr. Kiran R. Giri (MBBS, MD) is Associate Professor in Department of Pharmacology, Institute of Medical Sciences, Banaras Hindu University, Varanasi, India. Her Research interest is Ethnopharmacology, Reverse Pharmacology, Pharmacovigilance.

- Dr. Kamlesh M. Palandurkar (MBBS, MD, DNB, MNAMS) is Associate Professor in Department of Biochemistry, Institute of Medical Sciences, Banaras Hindu University, Varanasi, India. His Research interest is Clinical Genetics, Inborn error of Metabolism diagnosis and Research.

- Dr. Satish Chaurasia, Junior resident in Department of Pharmacology, Institute of Medical Sciences, Banaras Hindu University, Varanasi, India.

Cite this article: Giri K, Singh A, Palandurkar KM, Banerjee T, Chaurasia S. Evaluation of Antihelmintic Activity of Indigenous Plants Found in India Including Butea Monosperma, Origanum Majorana, Piper Longum and Embelia Ribes And GC-MS Phytochemica Analysis of Plant Extracts. Pharmacogn J. 2021;13(6): 1464-1471. 